\title{
INTERACTION OF Pu(VI) AND Np(VI) WITH CARBOHYDRAZIDE IN NITRIC ACID SOLUTIONS
}

\author{
O.A. Zavalina ${ }^{*}$, K.N. Dvoeglazov², E.Yu. Pavlyukevich², P.V. Nazarova², V.N. Alekseenko3 \\ ${ }^{1}$ D. Mendeleev University of Chemical Technology of Russia, Moscow, Russia \\ 2JSC A.A. Bochvar VNIINM, Moscow, Russia \\ 3FSUE “Mining Chemical Combine”, Zheleznogorsk, Russia
}

\begin{abstract}
The kinetics of $\mathrm{Pu}(V I)$ and $\mathrm{Np}(V I)$ recovery by carbohydrazide in an aqueous nitric acid solution was researched spectrophotometrically. Regarding to $\mathrm{Pu}(\mathrm{VI})$ it was established that in the interval of $\left[\mathrm{HNO}_{3}\right]=0.75-3 . \mathrm{O} \mathrm{M}$ and $\left[\mathrm{CO}\left(\mathrm{N}_{2} \mathrm{H}_{3}\right)_{2}\right]=0.1-0.4 \mathrm{M}$, the reaction rate was proportional to the concentration of Pu(VI). The reaction order with respect to carbohydrazide was determined to be 2.3, and -3 to nitric acid. The found activation energy of the reaction was $111 \mathrm{~kJ} \cdot \mathrm{mol}^{-1}$. Regarding $\mathrm{Np}(\mathrm{VI})$, it was found that in the interval of $\left[\mathrm{HNO}_{3}\right]=0.75-3.0 \mathrm{M}$ and $\left[\mathrm{CO}\left(\mathrm{N}_{2} \mathrm{H}_{3}\right)_{2}\right]=0.03-0.12 \mathrm{M}$, the reaction rate was proportional to the $\mathrm{Np}(\mathrm{VI})$ concentration. Reaction order with respect to carbohydrazide was determined to be 1.15 , and -1.35 with respect to nitric acid. The found activation energy of the reaction was $85 \mathrm{~kJ} \cdot \mathrm{mol}^{-1}$. Based on this kinetic data, a possible fundamental reaction mechanism was theorized.
\end{abstract}

Key words: Spent nuclear fuel, recovery, plutonium, neptunium, reduction, carbohydrazide, nitric acid

DOI: $10.21175 / \operatorname{RadProc} .2017 .08$

\section{INTRODUCTION}

In the development of a new hydrometallurgical technology of spent nuclear fuel reprocessing use of various organic reducing agents (substituted hydrazine, hydroxylamine and urea, oxime, etc.) was suggested to extract plutonium and neptunium and for their subsequent purification. The most promising reducing agents were carbohydrazide, $\mathrm{CO}\left(\mathrm{N}_{2} \mathrm{H}_{3}\right)_{2}$, hydrazine and urea derivative:<smiles>NNC(=O)NN</smiles>

In one of the options for mixed nitride uranium plutonium fuel processing, the fuel was dissolved in the concentrated nitric acid (8-10 mol/l). In the solution obtained, plutonium was in the form of a mixture of $\mathrm{Pu}(\mathrm{IV}, \mathrm{VI})$ [1], and neptunium was oxidized to Np (VI). These valent forms were well-extractable by tributylphosphate. In order to control the plutonium and neptunium reducing back-extraction process, it was necessary to know the nitric acid concentration influence and the reducing agent concentration influence on the interaction rate of $\mathrm{Pu}(\mathrm{VI})$ and $\mathrm{Np}(\mathrm{VI})$ with carbohydrazide.

\section{EXPERIMENTAL PART}

The study of the $\mathrm{Pu}(\mathrm{VI})$ and $\mathrm{Np}(\mathrm{VI})$ interaction was carried out by the spectrophotometry on Lambda-35
(Perkin-Elmer) by fixing changes in optical spectra at specified intervals. In the work a disposable optical cells with a path length of $10 \mathrm{~mm}$ were used. Nitric acid of $1 \mathrm{~mol} / \mathrm{l}$ was used as a blank solution.

The technique was as follows. A predetermined amount of nitric acid, plutonium(VI) nitrate and neptunium(VI) stock solutions was added to the optical cell. A cell with the solution was placed in a thermostatic cell holder, held for 10 minutes at the certain temperature and then an aliquot of the carbohydrazide stock solution was added. The spectra recording started after the 10 seconds of the solution stirring.

To study the kinetics of $\mathrm{Pu}(\mathrm{VI})$ and carbohydrazide interaction the optical spectra were recorded in a wavelength range from 450 to $950 \mathrm{~nm}$. The concentration of $\mathrm{Pu}(\mathrm{VI})$ was determined from the optical peak density at $830.5 \mathrm{~nm}$.

Since the $\mathrm{NpO}_{2}{ }^{2+}$ ions had no clear characteristic peaks in the spectrophotometer operating range (190$1100 \mathrm{~nm}$ ), the kinetics of $\mathrm{Np}(\mathrm{VI})$ and carbohydrazide interaction was studied by the $\mathrm{NpO}_{2}{ }^{+}$ions formation, which had a characteristic peak at $980 \mathrm{~nm}$.

To convert an optical density to the components concentration value the corresponding extinction coefficients depending on the nitric acid concentration were used.

\section{RESULTS AND DisCUSSION}

The interaction of the $\mathrm{Pu}(\mathrm{VI})$ with carbohydrazide. Observations for the spectrum changes in time showed $\mathrm{Pu}(\mathrm{VI})$ stepwise reducing. In Fig. 1 are shown the

*olga.zavalina.90@mail.ru 
changes in the optical spectra that occur during the reaction of plutonium ions with carbohydrazide. Peak optical density at $830.5 \mathrm{~nm}$ decreases, which corresponds to a decrease in the Pu (VI) concentration and simultaneously increasing the optical density peak at $570 \mathrm{~nm}$, which is characteristic of the $\mathrm{Pu}(\mathrm{V}) . \mathrm{Pu}(\mathrm{V})$ was initially formed at low acidity (less than $2 \mathrm{~mol} / \mathrm{l}$ ) and at the temperature below $30^{\circ} \mathrm{C}$, and only after the long-term holding $\mathrm{Pu}$ (III) was formed in the solution. In this case, peaks of absorbance appear at the spectra at 560 and $602 \mathrm{~nm}$, that is typical for Pu (III), and the peak at $570 \mathrm{~nm}$ decreases. With the increase of the temperature, nitric acid concentration or holding time (more than 7 hours), further reduction to $\mathrm{Pu}$ (III) happend. $\mathrm{Pu}(\mathrm{III})$ is the finite form of $\mathrm{Pu}(\mathrm{VI})$ and carbohydrazide interaction. The formation of tetravalent forms in conditions of the spectrophotometric study was not detected.

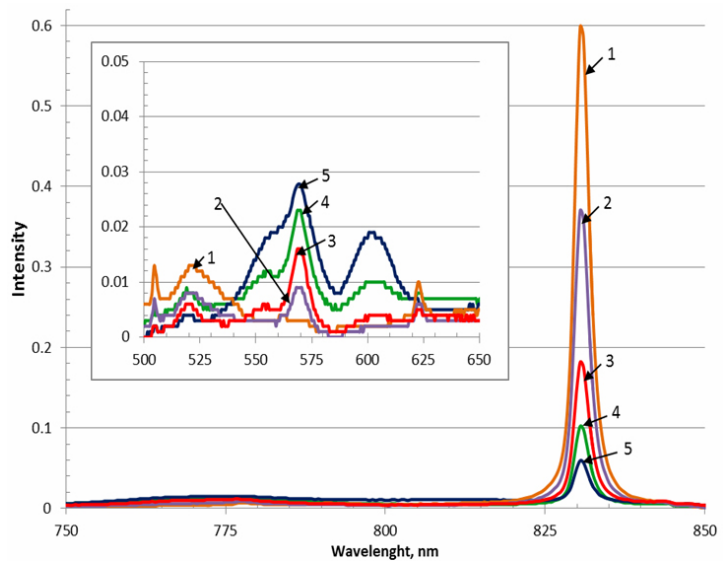

Figure 1. Changes in optical spectra after the carbohydrazide addition at $\left[\mathrm{HNO}_{3}\right]=1.57 \mathrm{~mol} / \mathrm{l},[\mathrm{Pu}(\mathrm{VI})]_{0}=0.001 \mathrm{~mol} / \mathrm{l}$,

$\left[\mathrm{CO}\left(\mathrm{N}_{2} \mathrm{H}_{3}\right)_{2}\right]=0.2 \mathrm{~mol} / \mathrm{l}$ and $20^{\circ} \mathrm{C} .1-0.5 \mathrm{~min} ; 2-30 \mathrm{~min}$; 3-84 min; 4- $144 \mathrm{~min} ; 5-239 \mathrm{~min}$

The processing of experimental data was performed assuming that the reaction proceeds according to the first order equation with respect to plutonium

$$
-\frac{d[P u(V I)]}{d t}=k \cdot[P u(V I)],
$$

where $\mathrm{k}$ - first-order rate constant, $\mathrm{min}^{-1}$.

By means of a graphic method in " $\ln [\mathrm{Pu}(\mathrm{VI})]-$ time" coordinates, the first order rate constants were determined for all studied conditions (Fig.2). According to the calculations, the increase of the solution acidity decreased the $\mathrm{Pu}(\mathrm{VI})$ reduction rate and growth of carbohydrazide concentration increased the reaction rate. Using the calculated rate constants, the reaction orders with respect to nitric acid and carbohydrazide were determined. The orders were equal to -3 and 2.3 respectively. The constancy of the reaction orders occurs if the nitric acid concentration was between 0.75 and $3.0 \mathrm{~mol} / \mathrm{l}$ and the reductant concentration was between 0.1 and $0.3 \mathrm{~mol} / \mathrm{l}$.

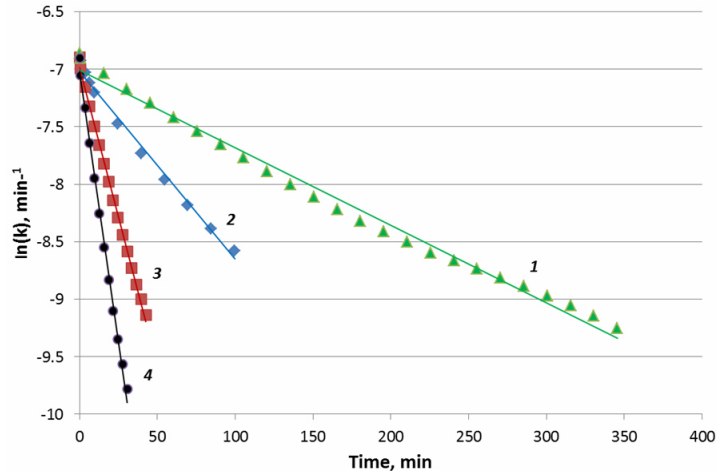

Figure 2. Plot of $\ln (\mathrm{k})$ vs. time in reduction of $\mathrm{Pu}(\mathrm{VI})$ with carbohydrazide. $[\mathrm{Pu}]=1 \times 10^{-3},\left[\mathrm{HNO}_{3}\right]=1 \mathrm{~mol} / 1,20^{\circ} \mathrm{C}$ and

$\left[\mathrm{CO}\left(\mathrm{N}_{2} \mathrm{H}_{3}\right)_{2}\right], \mathrm{mol} / \mathrm{l}: 1-0.1,2-0.15 ; 3-0.25 ; 4-0.3$

Based on the calculations of the reaction orders with respect to all components of the reaction system the general $\mathrm{Pu}(\mathrm{VI})$ and carbohydrazide interaction rate equation took the form

$$
-\frac{d[\mathrm{Pu}(\mathrm{VI})]}{d t}=k_{2} \cdot[\mathrm{Pu}(\mathrm{VI})] \cdot\left[\mathrm{HNO}_{3}\right]^{-3} \cdot\left[\mathrm{CO}\left(\mathrm{N}_{2} \mathrm{H}_{3}\right)_{2}\right]^{2.3},
$$

where $\mathrm{k}_{2}=(1.41 \pm 0.11) \mathrm{mol}^{0.7} /\left(\mathrm{l}^{0.7} \cdot \mathrm{min}\right)$ under $2 \mathrm{O}^{\circ} \mathrm{C}$.

The activation energy of the $\mathrm{Pu}(\mathrm{VI})$ reduction to the $\mathrm{Pu}(\mathrm{V})$ by carbohydrazide was calculated from the $\ln (\mathrm{k})$ and the inverse temperature $(1 / \mathrm{T})$ dependence was found to be $(111 \pm 11) \mathrm{kJ} / \mathrm{mol}$.

\section{The interaction of the $N p(V I)$ with carbohydrazide}

In the observation of the Np absorption spectra in time, it was revealed that the $\mathrm{Np}(\mathrm{VI})$ reduction process by carbohydrazide was going on until $\mathrm{Np}(\mathrm{V})$ formation.

It is noteworthy that during all the experiments the formation of $\mathrm{Np}$ (IV) was not observed for 4 hours after the carbohydrazide addition.

As it was found, an earlier [2] $\mathrm{Np}$ (IV) formation from the $\mathrm{Np}(\mathrm{V})$ was observed at $\left[\mathrm{HNO}_{3}\right] \geq 3 \mathrm{~mol} / \mathrm{l}$ and relatively high concentration of $\mathrm{CO}\left(\mathrm{N}_{2} \mathrm{H}_{3}\right)_{2}$ (more than $0.2 \mathrm{~mol} / \mathrm{l})$.

Similarly to $\mathrm{Pu}(\mathrm{VI})$, the processing of experimental data was performed, assuming the first reaction order with respect to the metal

$$
-\frac{d[N p(V I)]}{d t}=k_{1} \cdot[N p(V I)],
$$

The kinetic curves were transformed into straight lines in semi-logarithmic coordinates, the values of the rate constants $k_{1}$ were calculated from their slope. An example of the kinetic curves transformation is shown in Fig. 3. It was found that the order of the reaction with respect to nitric acid was -1.35 , and with respect to reductant 1.15, if the nitric acid concentration was between 0.75 and $3.0 \mathrm{~mol} / \mathrm{l}$ and the reductant concentration between 0.03 and $0.12 \mathrm{~mol} / \mathrm{l}$. 


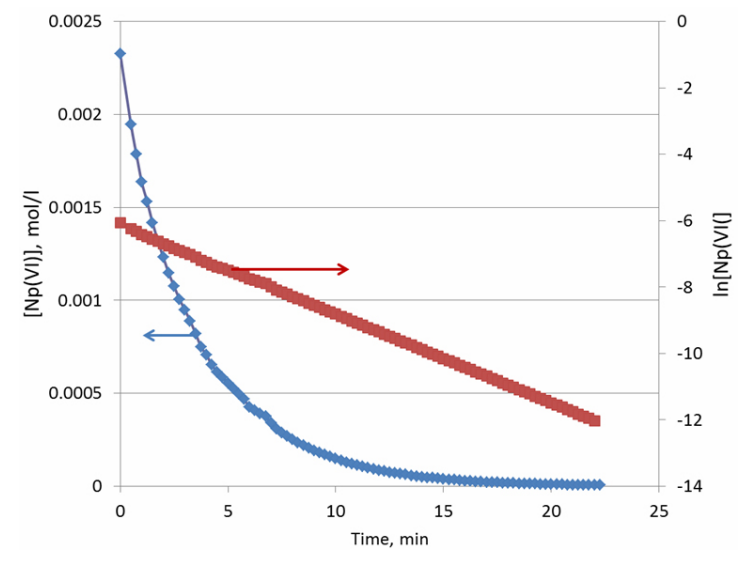

Figure 3. Kinetic curve of $\mathrm{Np}(\mathrm{VI})$ reduction and its linearization in semilog coordinates. $[\mathrm{Np}(\mathrm{VI})]=0.003$,

$\left[\mathrm{HNO}_{3}\right]=2$, and $\left[\mathrm{CO}\left(\mathrm{N}_{2} \mathrm{H}_{3}\right)_{2}\right]=0.03 \mathrm{~mol} / \mathrm{l}$ and $15^{\circ} \mathrm{C}$

Based on the calculations of the reaction orders with respect to all components of the reaction system, the general $\mathrm{Np}(\mathrm{VI})$ and $\mathrm{CO}\left(\mathrm{N}_{2} \mathrm{H}_{3}\right)_{2}$ interaction rate equation took the form

$-\frac{d[N p(V I)]}{d t}=k_{3} \cdot[N p(V I)] \cdot\left[H N O_{3}\right]^{-1,35} \cdot\left[C O\left(N_{2} H_{3}\right)_{2}\right]^{1,15}$,

where $\mathrm{k}_{3}=(39.7 \pm 2.7) \mathrm{mol}^{\mathrm{o} .2} /\left(\mathrm{l}^{\mathrm{o} .2} \cdot \mathrm{min}\right)$ under $15^{\circ} \mathrm{C}$.

The activation energy of the $\mathrm{Np}(\mathrm{VI})$ reduction to the $\mathrm{Np}(\mathrm{V})$ by the carbohydrazide was equal to $(85 \pm 20)$ $\mathrm{kJ} / \mathrm{mol}$.

\section{DiscuSSION OF THE REACTION SCHEME}

As one can see, the obtained kinetic equations (2) and (4) were similar: they had the first order with respect to the metal, the negative order with respect to the acid and fractional positive order with respect to the reductant. The found values of the carbohydrazide reaction orders differed from the data of the other studies on $\mathrm{Pu}(\mathrm{VI})$ and $\mathrm{Np}(\mathrm{VI})$ reduction with various organic hydrazine derivatives [3-6]. In most cases, the order of the reaction with respect to reducing agent was less than 1 . According to the author's opinion [4,5], the reaction of $\mathrm{Pu}(\mathrm{VI})$ and $\mathrm{Np}(\mathrm{VI})$ with substituted hydrazine occurred by a mechanism in a slow stage at which $\mathrm{Pu}^{4+}$ and $\mathrm{NpO}_{2}{ }^{2+}$ ions interact with neutral molecules of the reducing agent. Hydrazine derivatives are weak bases and therefore there was an equilibrium between the protonated and molecular form of the reducing agent in the presence of acid.

$$
\mathrm{RN}_{2} \mathrm{H}_{3}+\mathrm{H}^{+} \leftrightarrow \mathrm{RN}_{2} \mathrm{H}_{4}^{+}
$$

One can assume that this mechanism applied in the case of carbohydrazide:

$$
\mathrm{CO}\left(\mathrm{N}_{2} \mathrm{H}_{3}\right)_{2}+\mathrm{H}^{+} \leftrightarrow \mathrm{CO}\left(\mathrm{N}_{2} \mathrm{H}_{3}\right)\left(\mathrm{N}_{2} \mathrm{H}_{4}\right)^{+}
$$

More negative order with respect to the hydrogen in the reaction of $\mathrm{Pu}(\mathrm{VI})$ with $\mathrm{CO}\left(\mathrm{N}_{2} \mathrm{H}_{3}\right)_{2}$, and the fact that $\mathrm{Pu}(\mathrm{VI})$ was more hydrolysis-prone, unlike neptunium(VI), allowed to consider the hypothesis of $\mathrm{PuO}_{2} \mathrm{OH}^{+}$hydrolyzed forms interaction in slow reaction stages with carbohydrazide, which reacts in the form of uncharged molecules.

$$
\mathrm{PuO}_{2}{ }^{2+}+\mathrm{H}_{2} \mathrm{O} \leftrightarrow \mathrm{PuO}_{2} \mathrm{OH}^{+}+\mathrm{H}^{+} \text {(fast), }
$$

$\mathrm{PuO}_{2} \mathrm{OH}^{+}+\underset{+}{+} 2 \mathrm{CO}\left(\mathrm{N}_{2} \mathrm{H}_{3}\right)_{2}$

$\left[\mathrm{PuO}_{2} \mathrm{OH} \cdot 2 \mathrm{CO}\left(\mathrm{N}_{2} \mathrm{H}_{3}\right)_{2}\right]^{+}$(slowly),

Then a fast inner-sphere electron transition occurred in the $\left[\mathrm{PuO}_{2} \mathrm{OH} \cdot 2 \mathrm{CO}\left(\mathrm{N}_{2} \mathrm{H}_{3}\right)_{2}\right]^{+}$complex, leading to the $\mathrm{PuO}_{2}{ }^{+}$formation.

$\left[\mathrm{PuO}_{2} \mathrm{OH} \cdot 2 \mathrm{CO}\left(\mathrm{N}_{2} \mathrm{H}_{3}\right)_{2}\right]^{+}=\mathrm{PuO}_{2}{ }^{+}+\mathrm{CO}_{2}+\mathrm{H}_{2} \mathrm{O}+$ r.p. (fast).

It is known [7] that the uranyl ion formed complexes with carbohydrazide molecules and it was obtained in a solid form. It could be suggested that in the solutions with low acidity such complex can be formed with plutonyl and neptunyl ions. Since the ratedetermining stage in this mechanism was stage (8), the reduction rate was expressed by the ratio:

$$
-\frac{d[\mathrm{Pu}(\mathrm{VI})]}{d t}=k^{\prime} \cdot\left[\mathrm{PuO}_{2} \mathrm{OH}^{+}\right] \cdot\left[\mathrm{CO}\left(\mathrm{N}_{2} \mathrm{H}_{3}\right)_{2}\right]^{2},
$$

Similarly to the $\mathrm{Pu}$ (VI), it is possible to assume that $\mathrm{NpO}_{2}{ }^{2+}$ ion reacts with carbohydrazide through the complex formation by the reaction (11)

$$
\mathrm{NpO}_{2}{ }^{2+}+2 \mathrm{CO}\left(\mathrm{N}_{2} \mathrm{H}_{3}\right)_{2} \leftrightarrow\left(2 \mathrm{CO}\left(\mathrm{N}_{2} \mathrm{H}_{3}\right)_{2} \cdot \mathrm{NpO}_{2}\right)^{2+}
$$

and during the reaction (11) or after the complex formation, an inner-sphere electron transfer occurs in the complex $\left(2 \mathrm{CO}\left(\mathrm{N}_{2} \mathrm{H}_{3}\right)_{2} \cdot \mathrm{NpO}_{2}\right)^{2+}$ leading to the $\mathrm{NpO}_{2}+$ formation.

$\left(2 \mathrm{CO}\left(\mathrm{N}_{2} \mathrm{H}_{3}\right)_{2} \cdot \mathrm{NpO}_{2}\right)^{2+}=\mathrm{NpO}_{2}{ }^{+}+\mathrm{CO}_{2}+\mathrm{H}_{2} \mathrm{O}+$ reaction products

Fractional reaction orders for the reducing agent obtained in this study suggest that there was another parallel path of the $\mathrm{Pu}(\mathrm{VI})$ and $\mathrm{Np}(\mathrm{VI})$ interaction with carbohydrazide.

\section{CONCLUSION}

The kinetic equations that consider the effect of the nitric acid and carbohydrazide concentration on the reaction rate of $\mathrm{Pu}(\mathrm{VI})$ and $\mathrm{Np}(\mathrm{VI})$ reduction were determined. Based on the data obtained, the kinetic coefficient of the reactions and their activation energy were calculated. The resulting equations will be used in the development of mathematical models of the extraction processes based on oxidation-reduction processes.

The general dependences of the reducing agent and nitric acid effect for both metals are similar. There is a difference in the reaction orders with respect to both components. This observation can be explained in terms of the formation of complexes of CG with metal ions. It is possible that $\mathrm{PuO}_{2}{ }^{2+}$ forms a more stable complex with at least two molecules of CG. To verify this assumption, it is required to determine the CG complexation constants with $\mathrm{PuO}_{2}{ }^{2+}$ and $\mathrm{NpO}_{2}{ }^{2+}$.

\section{REFERENCES}

1. А.Ю. Шадрин, К.Н. Двоеглазов и др, "Взаимодействие модельного нитридного облучённого ядерного топлива с водой и азотной кислотой,"Вопросы радиационной безопасности, т. 72, но. 4, стр. 45 - 54, Июль 2013. (А. Yu. Shadrin, K. N. Dvoeglazov et al., "Interaction between Simulated Nitride Spent Nuclear Fuel and Water and Nitric Acid," 
Radiation safety issues, vol. 72, no. 4, pp. 45 - 54, Jul. 2013.)

2. V. I. Volk, V. I. Marchenko, K. N. Dvoeglazov et al., "Reduction of $\mathrm{Pu}(\mathrm{IV})$ and $\mathrm{Np}(\mathrm{VI})$ with Carbohydrazide in Nitric Acid Solution," Radiochemistry, vol. 54, no. 2, pp. 143-148, Apr. 2012.

DOI: $10.1134 / \mathrm{S} 1066362212020087$

3. V.S. Koltunov, V. G. Pastushyak, E. A. Mezhov, G. V. Koltunov, "Kinetics of Reactions of $\mathrm{Np}$ and $\mathrm{Pu}$ Ions with Hydrazine Derivatives: XVII. Reaction of $\mathrm{Pu}(\mathrm{VI})$ with Hydroxyethylhydrazine," Radiochemistry, vol. 46, no. 2, pp. 125 - 130, Mar. 2004.

DOI: 10.1023/B:RACH.ooooo24936.87231.co

4. В. С. Колтунов, Г. И. Журавлева, "Кинетика восстановления плутония гидразином. I. Восстановление плутония(У1),” Радиохимия, т. 15, но. 1, стр. $74-77$, 1973. (V.S. Koltunov, G. I. Zhuravlyeva, "Kinetics of Plutonium reduction by Hydrazine. I. Recovery of Plutonium(VI)," Radiochemistry, vol. 15, no. 1, pp. 74-77, 1973.)
5. V. I. Marchenko, V. N. Alekseenko, K. N. Dvoeglazov "Organic reductants of $\mathrm{Pu}$ and $\mathrm{Np}$ rons in wet technology for spent nuclear fuel reprocessing," Radiochemistry, vol. 57, no. 4. pp. 366-377, Jul. 2015. DOI: 10.1134/S1066362215040050

6. V.S. Koltunov, "Kinetics and Mechanism of RedOx Reactions of $\mathrm{Np}$ and $\mathrm{Pu}$ Ions with Several Organic Reductants," J. Nucl. Sci. and Techn., vol. 39, no. suppl. 3, pp. 347-350, Nov. 2002.

DOI: $10.1080 / 00223131.2002 .10875480$

7. D. Y. Leshok, V. N. Alekseenko, P. M. Gavrilov et al., "Uranyl tris - (carbohydrazide) nitrate

[UO2((N2H3)2CO)3](NO3)2: synthesis, structure and properties," Radiochimica Acta, vol. 103, no. 3, pp. 477-486, Jul. 2015.

DOI: $10.1515 /$ ract-2014-2337 